\title{
PERENCANAAN JALUR PENGANGKUTAN SAMPAH DI KABUPATEN BOGOR, KOTA BOGOR, DAN KOTA DEPOK MENUJU STASIUN PENGUMPUL ANTARA (SPA)
}

\author{
Deni Rusmaya*, Anni Rochaeni, Hendra Mulyana
}

Program Studi Teknik Lingkungan, Universitas Pasundan

\begin{abstract}
Abstrak
Sampah merupakan sisa kegiatan manusia dan/atau proses alam yang berbentuk padat. Berdasarkan hasil pengamatan, diketahui bahwa di ketiga daerah rencana (Kabupaten Bogor, Kota Bogor, dan Kota Depok) sudah tidak memiliki TPA yang layak. Oleh karena itu pihak provinsi menyediakan TPA terpadu yang dapat melayani ketiga daerah tersebut. maka diperlukannya perencanaan jalur operasional menuju TPA terpadu tersebut. Perencanaan jalur dibuat menuju Stasiun Pengumpul Antara (SPA) terlebih dahulu sebelum menuju TPA. Perencanaan ini dilakukan dengan cara menghitung terlebih dahulu jumlah timbulan sampah sampai akhir tahun perencanaan kemudian menganalisa jalur existing yang ada dan membuat jalur yang baru. Dari hasil penelitian didapat timbulan sampah yang terlayani sampai akhir tahun perencanaan yaitu Kabupaten Bogor mencapai 12.845,30 m3/hari dengan persentase pelayanan 58 $\%$ untuk daerah domestik. Sedangkan timbulan sampah non domestik akan mencapai 3.537,51 m3/hari dengan persen pelayanan $100 \%$. Kota Bogor mencapai 6.824,86 m3/hari dengan persentase pelayanan $100 \%$ untuk daerah domestik. Sedangkan timbulan sampah non domestik akan mencapai 219,47 m3/hari dengan persen pelayanan $100 \%$. Dan Kota Depok mencapai 11.179,43 m3/hari dengan persentase pelayanan $87 \%$ untuk daerah domestik. Sedangkan timbulan sampah non domestik akan mencapai $395,32 \mathrm{~m} 3 /$ hari dengan persen pelayanan $100 \%$. Dari hasil pengamatan di lapangan, maka dibuat jalur terbaik menurut waktu dan jarak tempuh pengumpulan dan pengangkutan. Dalam perencanaan ini dilakukan juga analisa terhadap data dan perhitungan yang mengacu pada literatur dan dengan rumusrumus yang ada dapat pula dihitung proyeksi kebutuhan armada sampai akhir tahun perencanaan.
\end{abstract}

Kata kunci: Jalur, pengangkutan, perencanaan, SPA, timbulan sampah, TPA.

\section{Pendahuluan}

Pengelolaan persampahan bila tidak dilakukan dengan baik akan banyak menimbulkan masalah, seperti permasalahan mengenai tumpukan sampah. Selain itu ketersediaan lahan dan kemampuan alam untuk mereduksi sampah masih sangat besar dan pada umumnya jenis

\footnotetext{
${ }^{*}$ Penulis Korespondensi:

E-mail: denirusmaya@gmail.com

Diterima pertama kali: 13 Desember 2017

Direvisi : 5 Februari 2018

Disetujui untuk publikasi: 7 Februari 2018
}

sampah yang ada merupakan sampah organik yang dengan mudah dapat direduksi oleh alam (Indriyanti, Banowati, \& Margunani, 2015 ).

Di Indonesia hampir semua kota menghadapi masalah persampahan. Beberapa di antaranya yaitu Kabupaten Bogor, Kota Bogor, dan Kota Depok. Saat ini Kabupaten Bogor memiliki empat TPA, yaitu TPA Pondok Rajeg, TPA Parung, TPA Galuga, dan TPA Jonggol. Akan tetapi keempat TPA tersebut sudah tidak bisa menampung sampah lagi. Untuk kota Bogor, Walaupun termasuk kota besar semimetropolis, 
tapi belum memiliki Tempat Pembuangan Akhir (TPA) sampah. Bertahun-tahun Kota Bogor membuang sampah ke TPA Galuga milik Pemkab Bogor. Sedangkan Kota Depok tidak memiliki Tempat Pembuangan Akhir (TPA) lagi setelah TPA di desa Cipatung Kecamatan Pancoran Mas tidak lagi menampung sampah yang diproduksi warga Depok. Sementara TPA milik Pemkab Bogor di Pondok Rajeg dinyatakan sudah tertutup menampung sampah dari Depok.

Untuk menyelesaikan persoalan sampah di tiga daerah tersebut, Pemerintah Provinsi Jawa Barat menetapkan Tempat Pengolahan dan Pembuangan Sampah Terpadu (TPPST) yang berlokasi di Desa Nambo dan Lulut, Kecamatan Klapanunggal Kabupaten Bogor sebagai tempat pembuangan sampah alternatif.

Tujuan dari Perencanaan Pengangkutan Sampah ini adalah untuk mendapatkan jalur pengangkutan dan waktu operasional pengangkutan yang optimal.

\section{Metodologi}

\section{Lokasi Perencanaan}

Perencanaan dilakukan untuk melayani pengelolaan sampah di Kabupaten Bogor, Kota Bogor, dan Kota Depok. Secara geografis Kabupaten Bogor terletak antara $106^{\circ} 1^{\prime}-107$ ${ }^{\circ} 103$ ' Bujur Timur dan antara $6^{\circ} 19^{\prime}-6^{\circ} 47^{\prime}$ Lintang Selatan, dengan wilayah seluas kira-kira $2.301,95 \mathrm{~km}^{2}$. Kota Bogor terletak di antara 106 43'30”BB - 106 51'00'BT dan 6 30 '30'LS - 6 $6^{\circ} 41^{\prime} 00$ 'LS. Kedudukan geografis Kota Bogor di tengah-tengah wilayah Kabupaten Bogor serta lokasinya sangat dekat dengan Ibukota Negara. Kota Depok merupakan wilayah termuda di Jawa Barat yang terbentuk pada tanggal 20 juni 1999. Secara geografis Kota Depok terletak pada koordinat $6^{\circ} 19^{\prime} 00^{\prime \prime}-6^{\circ} 28^{\prime} 00^{\prime \prime}$ Lintang Selatan dan $106^{\circ} 43^{\prime} 00^{\prime \prime}$ - $106^{\circ} 55^{\prime} 30^{\prime \prime}$ Bujur Timur. Kota Depok terletak di sebelah barat/utara wilayah Kabupaten Bogor dan berbatasan langsung dengan wilayah DKI Jakarta.

\section{Metode Perhitungan Timbulan Sampah}

Jumlah timbulan sampah akan meningkat dari tahun ke tahun sejalan dengan meningkatnya kegiatan dan jumlah penduduk perkotaan. Peningkatan timbulan sampah ini dapat dihitung dengan rumus (Damanhuri \& Padmi, 2004):

$$
q n=q o\left(1+\frac{C s}{100}\right)^{n}
$$

Dimana :

qn $=$ Debit timbulan sampah tahun ke $\mathrm{n}$

qo $=$ Debit timbulan sampah pada awal tahun

$\mathrm{Cs}=$ Prosentase peningkatan total tahun ke $\mathrm{n}$

$\mathrm{n}=$ Interval tahun perencanaan

$$
C s=\frac{1+1 / 3(C i+C g+C p)}{1+P}
$$

Dimana:

$\mathrm{Ci}=$ Presentase peningkatan industri konsumsi rata-rata pertahun

$\mathrm{Cg}=$ Presentase peningkatan income rata-rata pertahun

$\mathrm{Cp}=$ Presentase peningkatan hasil pertanian pertahun

$\mathrm{P}=$ Presentase peningkatan jumlah penduduk rata-rata pertahun

\section{Hasil dan Pembahasan}

\section{Proyeksi Timbulan Sampah}

Tabel 1, 2 dan 3 memperlihatkan masing-masing hasil perhitungan untuk proyeksi sampah Kabupaten Bogor, Kota Bogor, dan Kota Depok. 
Tabel 1. Tingkat Produksi Sampah Tiap Periode Perencanaan di Kabupaten Bogor

\begin{tabular}{ccccc}
\hline \multirow{2}{*}{ No. } & \multirow{2}{*}{ Tahun } & \multicolumn{2}{c}{ Timbulan Sampah } & \multirow{2}{*}{ Total Timbulan Sampah $\left(\mathbf{m}^{\mathbf{3}} / \mathbf{h a r i}\right)$} \\
\cline { 3 - 4 } & & Domestik $\left(\mathbf{m}^{\mathbf{3}} / \mathbf{h a r i}\right)$ & Non Domestik $\left(\mathbf{m}^{\mathbf{3}} / \mathbf{h a r i}\right)$ & $16.162,82$ \\
\hline 1 & 2016 & $13.287,60$ & $2.875,21$ & $16.759,46$ \\
\hline 2 & 2017 & $13.842,52$ & $2.916,94$ & $17.367,89$ \\
\hline 3 & 2018 & $14.408,64$ & $2.959,25$ & $17.988,30$ \\
\hline 4 & 2019 & $14.986,15$ & $3.002,15$ & $18.620,90$ \\
\hline 5 & 2020 & $15.575,25$ & $3.045,65$ & $19.268,64$ \\
\hline 6 & 2021 & $16.176,12$ & $3.092,52$ & $19.926,24$ \\
\hline 7 & 2022 & $16.788,96$ & $3.137,28$ & $20.596,64$ \\
\hline 8 & 2023 & $17.413,97$ & $3.182,67$ & $21.280,03$ \\
\hline 9 & 2024 & $18.051,35$ & $3.228,68$ & $21.988,15$ \\
\hline 10 & 2025 & $18.701,31$ & $3.286,85$ & $22.700,41$ \\
\hline 11 & 2026 & $19.364,04$ & $3.336,37$ & $24.424,27$ \\
\hline 12 & 2027 & $20.039,77$ & $3.384,50$ & $24.913,85$ \\
\hline 13 & 2028 & $20.728,71$ & $3.433,30$ & $25.684,58$ \\
\hline 14 & 2029 & $21.431,07$ & $3.482,78$ & \\
\hline 15 & 2030 & $22.147,07$ & $3.537,51$ & \\
\hline
\end{tabular}

Tabel 2. Tingkat Produksi Sampah Tiap Periode Perencanaan di Kota Bogor

\begin{tabular}{|c|c|c|c|c|}
\hline \multirow{2}{*}{ No. } & \multirow{2}{*}{ Tahun } & \multicolumn{2}{|c|}{ Timbulan Sampah } & \multirow{2}{*}{ Total Timbulan Sampah $\left(\mathrm{m}^{3} / \mathrm{hari}\right)$} \\
\hline & & Domestik (m³/hari) & Non Domestik $\left(\mathrm{m}^{3} / \mathrm{hari}\right)$ & \\
\hline 1 & 2016 & $4.444,21$ & 152,04 & $4.596,25$ \\
\hline 2 & 2017 & $4.595,07$ & 155,51 & $4.750,58$ \\
\hline 3 & 2018 & $4.748,70$ & 159,03 & $4.907,73$ \\
\hline 4 & 2019 & $4.905,16$ & 162,96 & $5.068,11$ \\
\hline 5 & 2020 & $5.064,47$ & 172,07 & $5.236,54$ \\
\hline 6 & 2021 & $5.226,68$ & 175,83 & $5.402,52$ \\
\hline 7 & 2022 & $5.391,85$ & 179,66 & $5.571,50$ \\
\hline 8 & 2023 & $5.560,00$ & 183,54 & $5.743,55$ \\
\hline 9 & 2024 & $5.731,20$ & 187,87 & $5.919,07$ \\
\hline 10 & 2025 & $5.905,49$ & 191,88 & $6.097,37$ \\
\hline 11 & 2026 & $6.082,90$ & 195,97 & $6.278,87$ \\
\hline 12 & 2027 & $6.263,50$ & 200,12 & $6.463,62$ \\
\hline 13 & 2028 & $6.447,33$ & 204,34 & $6.651,66$ \\
\hline 14 & 2029 & $6.634,43$ & 209,02 & $6.843,45$ \\
\hline 15 & 2030 & $6.824,86$ & 219,47 & $7.044,33$ \\
\hline
\end{tabular}

Tabel 3. Tingkat Produksi Sampah Tiap Periode Perencanaan di Kota Depok

\begin{tabular}{ccccc}
\hline \multirow{2}{*}{ No. } & \multirow{2}{*}{ Tahun } & \multicolumn{2}{c}{ Timbulan Sampah } & \multirow{2}{*}{ Total Timbulan Sampah $\left(\mathbf{m}^{\mathbf{3}} / \mathbf{h a r i}\right)$} \\
\cline { 3 - 4 } & & Domestik $\left(\mathbf{m}^{\mathbf{3}} / \mathbf{h a r i}\right)$ & Non Domestik $\left(\mathbf{m}^{\mathbf{3}} / \mathbf{h a r i}\right)$ & $7.933,12$ \\
\hline 1 & 2016 & $7.708,37$ & 224,75 & $8.265,78$ \\
\hline 2 & 2017 & $8.031,79$ & 233,99 & $8.604,77$ \\
\hline 3 & 2018 & $8.361,36$ & 243,41 & $8.950,17$ \\
\hline 4 & 2019 & $8.697,18$ & 252,99 & $9.309,32$ \\
\hline 5 & 2020 & $9.039,34$ & 269,98 & $9.676,37$ \\
\hline 6 & 2021 & $9.387,94$ & 288,43 & $10.041,82$ \\
\hline 7 & 2022 & $9.743,08$ & 298,74 & $10.414,11$ \\
\hline 8 & 2023 & $10.104,87$ & 309,24 & $10.793,34$ \\
\hline 9 & 2024 & $10.473,40$ & 319,93 & $11.179,61$ \\
\hline 10 & 2025 & $10.848,79$ & 330,83 & $11.573,18$ \\
\hline 11 & 2026 & $11.231,13$ & 342,05 & $11.973,88$ \\
\hline 12 & 2027 & $11.620,53$ & 353,35 & $12.381,95$ \\
\hline 13 & 2028 & $12.017,11$ & 364,85 & $7.933,12$ \\
\hline 14 & 2029 & $7.708,37$ & 224,75 & $8.265,78$ \\
\hline 15 & 2030 & $8.031,79$ & 233,99 & \\
\hline
\end{tabular}




\section{Tingkat Pelayanan}

Saat ini tingkat pelayanan sampah di daerah perencanaan adalah untuk Kabupaten Bogor 32 $\%$, Kota Bogor 68,55 \%, dan Kota Depok 43,66 $\%$. Direncanakan tingkat pelayanan sampai tahun 2030 adalah untuk Kabupaten Bogor, 58 $\%$ untuk daerah permukiman dan $100 \%$ untuk daerah Komersil. Untuk Kota Bogor, $100 \%$ untuk daerah permukiman dan komersil. Dan untuk Kota Depok, $87 \%$ untuk daerah permukiman dan $100 \%$ untuk daerah komersil. Besarnya volume sampah yang terlayani di daerah perencanaan sampai tahun 2030 dapat dilihat pada Tabel 4, 5, dan 6 .

Tabel 4. Total Timbulan Sampah yang Terlayani di Kab. Bogor

\begin{tabular}{|c|c|c|c|c|c|}
\hline \multirow{2}{*}{ Tahun } & \multicolumn{4}{|c|}{ Timbulan Sampah Yang Terlayani(m³/hr) } & \multirow{2}{*}{$\begin{array}{c}\text { Total Timbulan Sampah yang } \\
\text { Terlayani }\left(\mathrm{m}^{3} / \mathrm{hr}\right)\end{array}$} \\
\hline & \% Pelayanan & Domestik & \% Pelayanan & Non Domestik & \\
\hline 2018 & 34 & $4.898,94$ & 100 & $2.959,25$ & $7.858,19$ \\
\hline 2019 & 36 & $5.395,01$ & 100 & $3.002,15$ & $8.397,17$ \\
\hline 2020 & 38 & $5.918,59$ & 100 & $3.045,65$ & $8.964,25$ \\
\hline 2021 & 40 & $6.470,45$ & 100 & $3.092,52$ & $9.562,97$ \\
\hline 2022 & 42 & $7.051,36$ & 100 & $3.137,28$ & $10.188,65$ \\
\hline 2023 & 44 & $7.662,15$ & 100 & $3.182,67$ & $10.844,81$ \\
\hline 2024 & 46 & $8.303,62$ & 100 & $3.228,68$ & $11.532,30$ \\
\hline 2025 & 48 & $8.976,63$ & 100 & $3.286,85$ & $12.263,47$ \\
\hline 2026 & 50 & $9.682,02$ & 100 & $3.336,37$ & $13.018,39$ \\
\hline 2027 & 52 & $10.420,68$ & 100 & $3.384,50$ & $13.805,18$ \\
\hline 2028 & 54 & $11.193,50$ & 100 & $3.433,30$ & $14.626,80$ \\
\hline 2029 & 56 & $12.001,40$ & 100 & $3.482,78$ & $15.484,18$ \\
\hline 2030 & 58 & $12.845,30$ & 100 & $3.537,51$ & $16.382,81$ \\
\hline
\end{tabular}

Tabel 5. Total Timbulan Sampah yang Terlayani di Kota Bogor

\begin{tabular}{lccccc}
\hline \multirow{2}{*}{ Tahun } & \multicolumn{3}{c}{ Timbulan Sampah Yang Terlayani(m3/hr) } & Total Timbulan Sampah yang \\
\cline { 2 - 5 } & \% Pelayanan & Domestik & \% Pelayanan & Non Domestik & Terlayani (m3/hr) \\
\hline 2018 & 82 & $3.885,86$ & 100 & 159,03 & $4.044,89$ \\
\hline 2019 & 83 & $4.087,47$ & 100 & 162,96 & $4.250,42$ \\
\hline 2020 & 85 & $4.296,19$ & 100 & 172,07 & $4.468,26$ \\
\hline 2021 & 86 & $4.512,20$ & 100 & 175,83 & $4.688,03$ \\
\hline 2022 & 88 & $4.735,66$ & 100 & 179,66 & $4.915,32$ \\
\hline 2023 & 89 & $4.966,75$ & 100 & 183,54 & $5.150,30$ \\
\hline 2024 & 91 & $5.205,65$ & 100 & 187,87 & $5.393,52$ \\
\hline 2025 & 92 & $5.452,53$ & 100 & 191,88 & $5.644,42$ \\
\hline 2026 & 94 & $5.707,59$ & 100 & 195,97 & $5.903,56$ \\
\hline 2027 & 95 & $5.970,99$ & 100 & 200,12 & $6.171,11$ \\
\hline 2028 & 97 & $6.242,94$ & 100 & 204,34 & $6.447,28$ \\
\hline 2029 & 98 & $6.523,63$ & 100 & 209,02 & $6.732,65$ \\
\hline 2030 & 100 & $6.824,86$ & 100 & 219,47 & $7.044,33$ \\
\hline
\end{tabular}


Tabel 6. Total Timbulan Sampah yang Terlayani di Kota Depok

\begin{tabular}{lccccc}
\hline \multirow{2}{*}{ Tahun } & \multicolumn{3}{c}{ Timbulan Sampah Yang Terlayani(m3/hr) } & Total Timbulan Sampah yang \\
\cline { 2 - 5 } & \% Pelayanan & Domestik & \% Pelayanan & Non Domestik & Terlayani (m3/hr) \\
\hline 2018 & 63 & $5.277,69$ & 100 & 243,41 & $5.521,10$ \\
\hline 2019 & 65 & $5.663,60$ & 100 & 252,99 & $5.916,59$ \\
\hline 2020 & 67 & $6.067,20$ & 100 & 269,98 & $6.337,18$ \\
\hline 2021 & 69 & $6.488,94$ & 100 & 288,43 & $6.777,37$ \\
\hline 2022 & 71 & $6.929,28$ & 100 & 298,74 & $7.228,02$ \\
\hline 2023 & 73 & $7.388,68$ & 100 & 309,24 & $7.697,92$ \\
\hline 2024 & 75 & $7.867,62$ & 100 & 319,93 & $8.187,55$ \\
\hline 2025 & 77 & $8.366,59$ & 100 & 330,83 & $8.697,41$ \\
\hline 2026 & 79 & $8.886,07$ & 100 & 342,05 & $9.228,12$ \\
\hline 2027 & 81 & $9.426,58$ & 100 & 353,35 & $9.779,92$ \\
\hline 2028 & 83 & $9.988,62$ & 100 & 364,85 & $10.353,47$ \\
\hline 2029 & 85 & $10.572,73$ & 100 & 376,56 & $10.949,28$ \\
\hline 2030 & 87 & $11.179,43$ & 100 & 395,32 & $11.574,75$ \\
\hline
\end{tabular}

\section{Sistem Operasional Pengangkutan Sampah}

Mekanisme sistem pengangkutan sampah di Kabupaten Bogor adalah sebagai berikut (Gambar 1.):

1. Kendaraan pengangkut sampah berangkat dari pool dalam keadaan kosong menuju sumber sampah pertama di daerah pelayanan yang telah ditentukan.

2. Setelah sampai di sumber sampah pertama, petugas memindahkan sampah dari wadah individu atau komunal ke dalam truk dengan menggunakan keranjang plastik.

3. Dua orang petugas memasukkan sampah dari wadah sampah ke dalam keranjang dengan menggunakan garpu, dua orang petugas menaikkan keranjang yang berisi sampah ke atas kendaraan pengangkut, dan satu orang petugas berada di atas kendaraan pengangkut untuk menerima keranjang dan meratakan sampahnya. Hal tersebut dilakukan dari sumber sampah pertama sampai sumber sampah terakhir.

4. Setelah kendaraan pengangkut penuh, lalu kendaraan pengangkut ditutup dengan menggunakan terpal agar sampahnya tidak tercecer di jalan.

5. Kemudian kendaraan pengangkut berangkat ke TPA.

Sistem operasional pengangkutan sampah di Kota Depok adalah sebagai berikut (Gambar 2):

1. Truk berangkat dari pool menuju sumber timbulan sampah pertama di daerah pelayanan dalam keadaan kosong.

2. Melakukan pemindahan sampah dari wadah sampah individu maupun komunal ke dalam truk.

3. Dua orang petugas memasukan sampah dari tiap wadah ke dalam keranjang dengan garpu, seorang petugas mengangkat keranjang tersebut ke atas truk, dan satu orang petugas menerima keranjang dan meratakan sampahnya di atas truk.

4. Setelah truk penuh, maka truk ditutup dengan menggunakan terpal, lalu berangkat menuju TPA. 


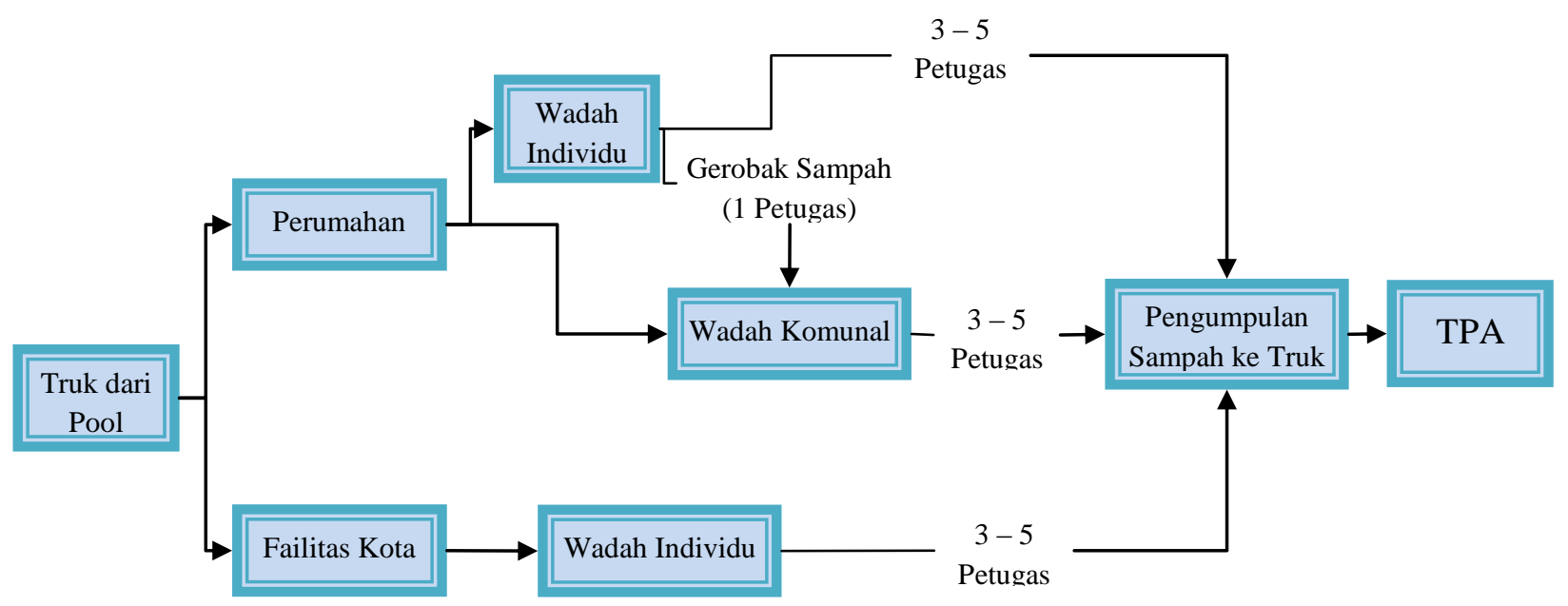

Gambar 1. Sistem Operasional Pengangkutan Sampah di Kabupaten Bogor

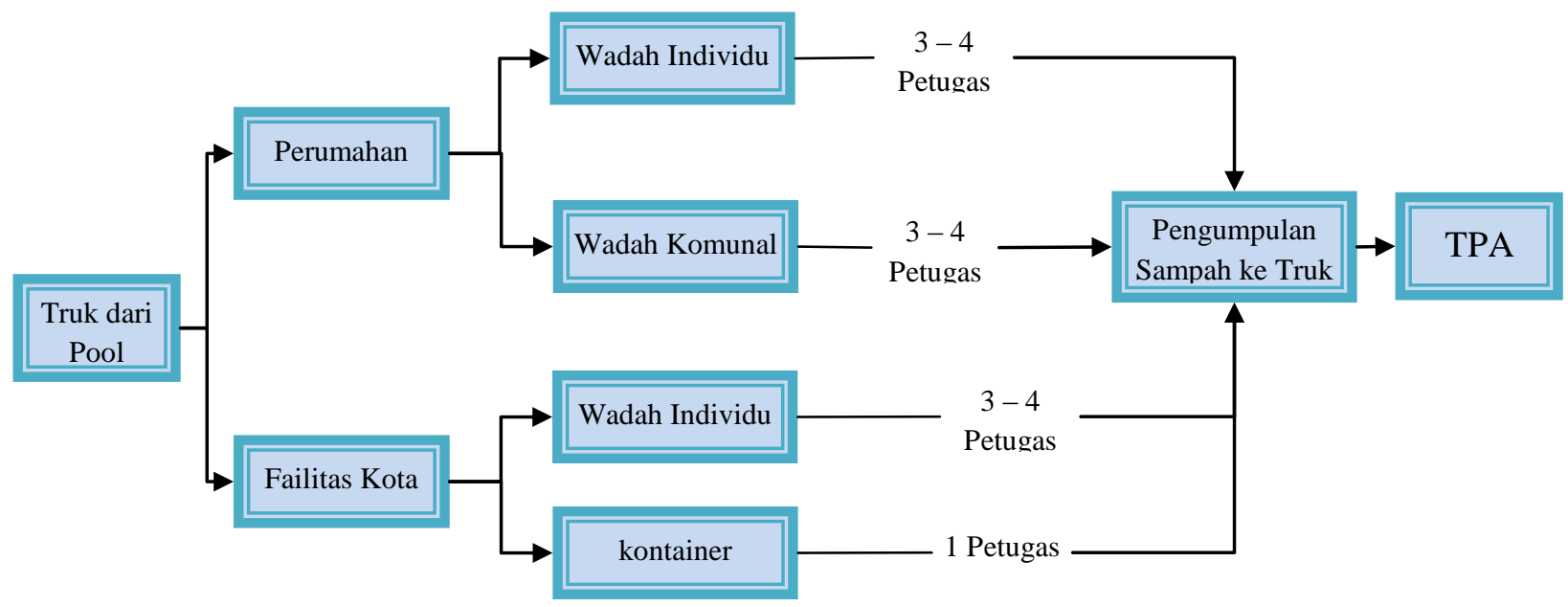

Gambar 2. Sistem Operasional Pengangkutan Sampah di Kota Bogor

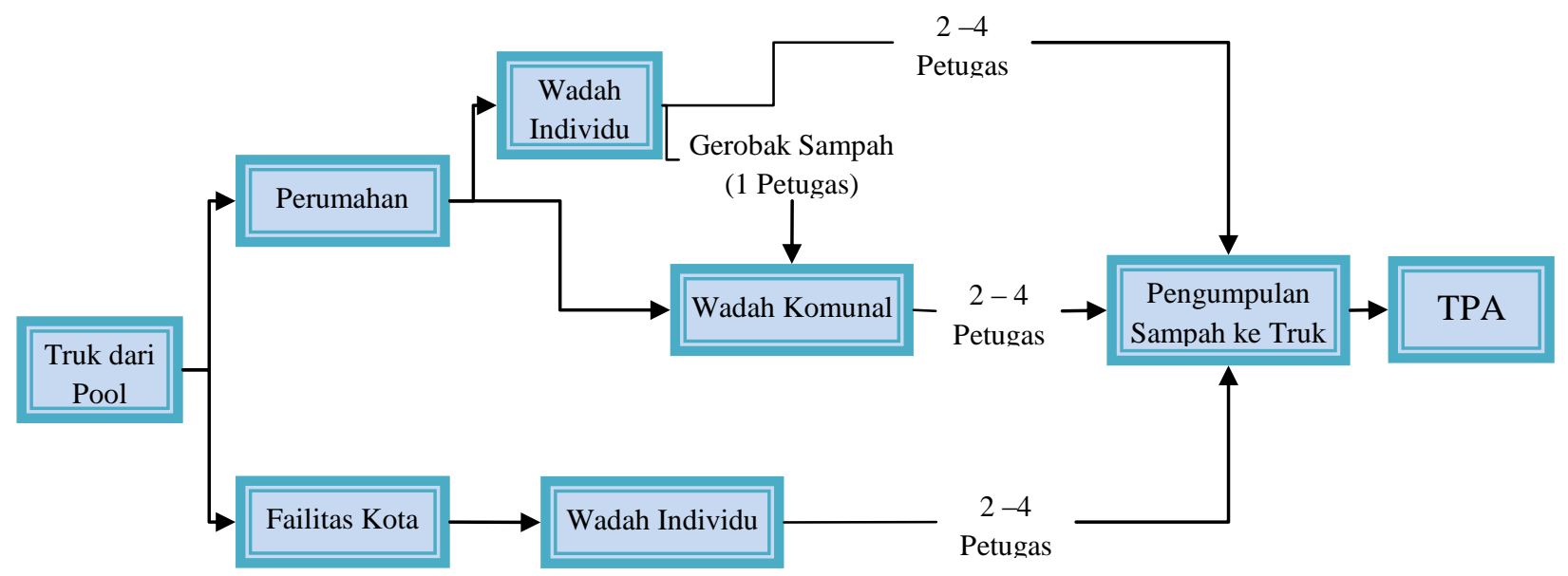

Gambar 3. Sistem Operasional Pengangkutan Sampah di Kota Depok 
Sistem operasional pengangkutan sampah di Kota Depok adalah sebagai berikut :

1. Truk berangkat dari pool menuju sumber timbulan sampah pertama di daerah pelayanan dalam keadaan kosong.

2. Melakukan pemindahan sampah dari wadah sampah individu maupun komunal ke dalam truk.

3. Dua orang petugas memasukan sampah dari tiap wadah ke dalam keranjang dengan garpu, seorang petugas mengangkat keranjang tersebut ke atas truk, dan satu orang petugas menerima keranjang dan meratakan sampahnya di atas truk.

4. Setelah truk penuh, maka truk ditutup dengan menggunakan terpal, lalu berangkat menuju TPA.

Pelayanan pengangkutan sampah di daerah yang meliputi Kabupaten Bogor, Kota Bogor dan Kota Depok adalah sebagai berikut:

a. Untuk wilayah Kabupaten Bogor, waktu yang dibutuh dalam proses pengumpulan dan pengangkutan sampah rata-rata 477,66 menit atau sekitar 7,96 jam per ritasi per hari. Hal ini disebabkan karena daerah pelayanan dan Tempat Pembuangan Sampah (TPA) berjauhan. Ditambah dengan jalur lalu lintas yang padat sehingga memperlambat perjalanan. Untuk contoh, kendaraan pengangkut dengan nomor kendaraan $\mathrm{F} 8145$ $\mathrm{F}$, menempuh jarak sekitar $19 \mathrm{~km}$ dari pool ke daerah pelayanan (Kecamatan Gunung Putri) dengan waktu 54,92 menit. Kemudian membuang sampahnya ke TPA di Kecamatan Cibungbulang yang berjarak 50,8 km dengan maktu perjalanan 128,07 menit.

b. Untuk wilayah Kota Bogor, dalam proses pengumpulan dan pengangkutan sampah waktu yang dibutuhkan rata-rata 6,94 jam per ritasi per hari. Waktu tercepat yaitu kendaraan dengan nomor F 8341 A, sedangkan yang waktunya paling lama adalah kendaraan dengan nomor F 8215 A. Dilihat dari rata-rata tersebut, waktu pengumpulan dan pengangkutan sampah di Kota Bogor relatif lama. Hal ini disebabkan oleh tempat pembuangan berada di luar wilayah Kota Bogor. Ditambah lagi terbatasnya petugas pengumpulan dan pengangkutan.

c. Untuk wilayah Kota Depok, proses pengumpulan dan pengangkutan sampah lebih cepat dibandingkan wilayah Kabupaten Bogor dan Kota Depok. Yaitu rata-rata waktu 4,58 jam per ritasi per hari. Hal itu disebabkan karena lokasi pembuangan yang lebih dekat.

\section{Kesimpulan}

Dari hasil pengamatan di lapangan dan perhitungan maka kesimpulan yang dapat diambil adalah :

1. Sampai akhir tahun perencanaan timbulan sampah domestik Untuk Kabupaten Bogor yang terlayani mencapai $12.845,30 \mathrm{~m}^{3} /$ hari $\mathrm{m}^{3} /$ hari dengan persentase pelayanan $58 \%$. Sedangkan timbulan sampah non domestik akan mencapai $3.537,51 \mathrm{~m}^{3} /$ hari dengan persen pelayanan $100 \%$. Untuk Kota Bogor, domestik $6.824,86 \mathrm{~m}^{3} /$ hari dan non domestik $219,47 \mathrm{~m}^{3} /$ hari dengan persentase pelayanan $100 \%$. Dan untuk Kota Depok, domestik $11.179,43 \mathrm{~m}^{3} /$ hari dengan persentase $87 \%$ dan non domestik 395,32 $\mathrm{m}^{3} /$ hari dengan persentase $100 \%$.

2. Sistem pengangkutan sampah secara langsung di Kabupaten Bogor, Kota Bogor, dan Kota Depok dilakukan dengan menggunakan dump truk

3. Kabupaten Bogor mempunyai 2 (dua) Stasiun Pengumpul Antara (SPA) yang terletak di Kecamatan Ciawi dan Kecamatan Gunung Putri. Sedangkan Kota Bogor 
memiliki 1 (satu) SPA yang terletak di Kecamatan Bogor Tengah. Dan Kota Depok memiliki 1 (satu) SPA yang terletak di Kecamatan Cimanggis.

Waktu Operasional jalur pengumpulan dan pengangkutan sampah Kabupaten Bogor adalah 160,02 jam dengan jarak tempuh 1186,66 km. Untuk Kota Bogor adalah 32,98 jam dengan jarak tempuh 95,04 km. Dan untuk Kota Depok adalah 34,19 jam dengan jarak tempuh 192,73 $\mathrm{km}$.

\section{Daftar Pustaka}

Damanhuri, E., \& Padmi, T. (2004). Diktat Pengelolaan Sampah. Bandung: Penerbit TL ITB.

Indriyanti, D. R., Banowati, E., \& Margunani, M. (2015 ). Pengolahan Limbah Organik Sampah Pasar Menjadi Kompos . Jurnal Abdimas, Vol. 19 No. 1: 43-48. 